\title{
MIGRASI INTERNASIONAL PERILAKU PEKERJA MIGRAN DI MALAYSIA DAN PEREMPUAN DITINGGAL MIGRASI DI LOMBOK TIMUR
}

\author{
Lalu Tajuddin \\ Fakultas Keguruan dan Ilmu Pendidikan \\ Universitas Muhammadiyah Mataram- Nusa Tenggara Barat \\ Email: eltajudien@gmail.com \\ R. Rijanta, Hadi Sabari Yunus, dan Sri Rum Giyarsih \\ Fakultas Geografi Universitas Gadjah Mada
}

\begin{abstract}
The goal of the research is to examine the behavior of migrant workers and PADMI. The research is located in Eastern Malaysia and East Lombok Regency by using case study method to explore the objects deeply, detailed and complete. Data were collected through observation and in-depth interview with the migrant workers and PADMI. The research showed that Ringgit or Malaysian currency contribute significant influence to the migrant workers' behavior, which showed by the change of their fashion style, pattern of consumption, increasing entertainment needs and also the augmentation of consumptive life style. The consumptive life style is a new reality and relatively common, while to fulfill sexual needs the workers opted to marry the other female migrant workers because it was considered more save, more economical and also could prevent them from the contamination of sexual disease. At the other side, PADMI has not only principal role in fulfilling the family life needs but also must attempt to maintain the completeness and harmony of the family/household. The inclination of having seductive and sexual discomfiture from the other man is experienced often by PADMI, and sometimes could be ended in court. Without considering the economic impact, the high number of sued divorce in hometown of migrant workers gave evidence that migration activity ruin the family life of the migrant workers.
\end{abstract}

Keywords: Behavior; Migrant workers; Consumptive; and PADMI

\begin{abstract}
ABSTRAK
Penelitian ini bertujuan mengkaji perilaku pekerja migran dan Perempuan Ditinggal Migrasi (PADMI). Lokasi penelitian di Malaysia Timur dan Kabupaten Lombok Timur (LOTIM), menggunakan metode studi kasus untuk mencitrakan obyek secara mendalam, rinci dan lengkap. Pengumpulan data menggunakan observasi dan wawancara mendalam terhadap pekerja migran dan PADMI. Hasil penelitian menunjukkan pengaruh pendapatan terhadap perilaku pekerja migran relatif besar, terlihat dari mode berpakaian, pola konsumsi, kebutuhan hiburan dan sifat konsumtif. Pola hidup konsumtif terlihat nyata dan relatif sama, sedangkan untuk pemenuhan kebutuhan seksual pekerja migran memilih menikah sesama pekerja dengan alasan lebih aman, irit dan takut tertular penyakit. Pada bagian lain tugas utama PADMI tidak hanya pemenuhan kebutahan hidup, tetapi menjaga dan mempertahankan
\end{abstract}


keutuhan rumah tangganya. Kecendrungan PADMI mendapat gangguan pihak ketiga sangat besar dan tidak jarang berakhir di meja pengadilan. Tanpa mengabaikan dampak ekonomis, tingginya angka cerai gugat di daerah pengirim membuktikan aktivitas migrasi merusak konstruksi rumah tangga pekerja migran.

Kata kunci: Perilaku; Pekerja Migran; Konsumtif; dan PADMI

\section{PENGANTAR}

Volume migrasi mengalami peningkatan, selain itu permasalahan yang dihadapi pekerja migran maupun keluarga semakin kompleks. Dewasa ini tema yang sering diangkat dalam beberapa penelitian tenaga kerja seperti: pengiriman dan pemanfaatan remitan, determinan aktivitas migrasi, migrasi dan pembangunan, perilaku seksual pekerja migran,. dan dampak sosial lainnya. Penelitian yang secara spesifik mengkaji perilaku pekerja migran di daerah tujuan dan Perempuan Ditinggal Migrasi (PADMI) belum banyak dilakukan.

Permasalahan bidang ketenagakerjaan terutama peningkatan jumlah angkatan kerja di Indonesia dan khususnya di Nusa Tenggara Barat (NTB) berimplikasi terhadap kebijakan pemerintah, keadaan ekonomi dan strukutur sosial masyarakat. Salah satu fenomena yang terjadi akibat kondisi di atas adalah peningkatan jumlah pergerakan penduduk sebagai pekerja migran setiap tahun. Sebagai gambaran, pada tahun 2007 - 2011 TKI yang ditempatkan sebanyak 263.518 orang (BP3TKI NTB, 2011).

Secara nyata aktivitas migrasi internasional menyebabkan berbagai dampak baik bagi diri, rumah tangga maupun daerah asal pekerja migran. Salah satu dampak yang dapat diamati di daerah pengirim pekerja migran berupa keretakan rumah tangga, yang ditunjukkan dengan tingginya angka cerai gugat. Keretakan rumah tangga sebagai akibat dari perilaku pekerja migran di daerah tujuan terutama Malaysia, dapat pula disebabkan PADMI di daerah asal khususnya Lombok Timur (LOTIM). Jumlah penduduk asal LOTIM yang bekerja ke
Malaysia relatif tinggi, hal ini ditunjukkan jumlah pergerakan penduduk usia produktif dari wilayah ini mengalami peningkatan. Tahun 2006 hingga 2011 Kabupaten LOTIM menempatkan pekerja migran di Malaysia sebayak 85.536 orang. Bahkan pada tahun 2007 sampai dengan 2011, dari 263.518 orang pekrja migran asal NTB, sebanyak 73.660 orang atau sekitar $27,9 \%$ berasal dari Kabupaten LOTIM (Disosnakertans LOTIM, 2012).

Mengacu dari permasalahan di atas, maka pertanyaan penelitian (research questions) adalah bagaimana perilaku pekerja migran selama di Malaysia dan PADMI di daerah asal. Adapun tujuan penelitian ini mengkaji perilaku pekerja migran selama di luar negeri dan PADMI di daerah asal. Penelitian bertema migrasi internasional di Indonesia banyak dilakukan, tetapi variasi tekanan dan obyek penelitiannya menghasilkan dimensi yang berbeda-beda. Penelitian migrasiyang pernah dilakukan antara lain dikerjakan oleh Goma (1993), Mantra (1999), Hugo (2001), Haris (2004), dengan tekanan utama pada fenomena sosialekonomi. Penelitian lain yang sejalan pernah dilakukan yaitu terkait dengan struktur dan komposisi keluarga, kepemimpinan keluarga, perkawinan dan perceraian, hubungan antargenerasi, perawatan anak, keadaan ekonomi keluarga, peran serta status wanita, dan hubungan kekuasaan dalam keluarga (Hugo, 2001; Castles, 2009; Sevoya, Yabiku dan Agadjanian, 2010).

Berkembangnya perhatian terhadap penelitian migrasi terutama migrasi internasional tidak lepas berbagai masalah dalam ranah ini mulai dari yang sederhana hingga rumit. Terjadinya perpisahan dalam waktu relatif lama antara pekerja migran dan istri menimbulkan dampak pada perilaku. Perilaku manusia pada hakikatnya merupakan suatu aktivitas dari manusia itu sendiri, sehingga perilaku memiliki bentangan yang sangat luas mencakup: berjalan, berbicara, bereaksi, dan berpakaian. Bahkan kegiatan internal (internal activity) seperti berpikir, persepsi, 
dan emosi merupakan perilaku manusia (Notoatmodjo, 2003). Perilaku dan gejalanya yang tampak pada kegiatan manusia dapat dipengaruhi oleh faktor genetik (keturunan) dan lingkungan. Kedua faktor tersebut dapat dikatakan sebagai faktor penentu perilaku manusia. Faktor hereditas merupakan dasar untuk perkembangan perilaku selanjutnya. Sedangkan lingkungan adalah kondisi atau lahan untuk perkembangan perilaku tersebut.

Kuatnya tekanan oleh situasi tertentu ditanggapi berbeda-beda oleh setiap orang walaupun dalam kondisi yang sama. Fishbhein dan Ajzen; Ajzen dan Fisbhein dalam Taylor et al., 2009 mengemukakan teori tindakan yang beralasan. Teori ini berusaha menunjukkan faktor-faktor yang menentukan sikap-perilaku dengan asumsi bahwa manusia berperilaku sesuai dengan niat sadar yang didasarkan pada kalkulasi rasional tentang efek potensial dari perilaku dan bagaimana orang lain akan memandang perilaku tersebut. Perilaku adalah apa yang dikerjakan oleh organisme baik yang dapat diamati secara langsung maupun tidak langsung. Terkait penelitian yang dilakukan perilaku pekerja migran dimaksud menyangkut hal-hal yang dapat diindera melalui observasi, termasuk respon terhadap kondisi yang dialami baik negatif maupun positif. Respon negatif seorang pekerja migran seperti tidak mengirim kabar dan remitan disadari berdampak pada kelangsungan hidup keluarganya, tetapi hal itu tetap dilakukan. Bentuk perilaku seorang pekerja migran yang demikian dikatakan sebagai perilaku aktif.

Munculnya dampak positif maupun negatif dalam aktivitas migrasi internasional tidak luput dari kondisi internal dan eksternal migran dan rumah tangganya. Kondisi internal yang berasal dari dalam diri individu seperti kondisi psikologis, sedangkan kondisi eksternal berasal dari luar individu seperti: tingkat stress yang dialami akibat volume dan tekanan kerja, kondisi tempat bekerja, pengaruh teman sejawat, jauh dari pengawasan keluarga, dan tersedianya fasilitas hiburan. Beberapa hasil penelitian menunjukkan bahwa pengaruh faktor ekternal di daerah tujuan cukup menentukan sehingga tidak jarang para migran gagal mempertahankan kelangsungan rumah tangganya.

Sebagai salah satu kantong migran di Indonesia, Kabupaten Lombok Timur menghadapi masalah terkait dampak aktivitas migrasi. Salah satu masalah yang sampai saat ini belum mendapat perhatian sebagaimana diuraikan di atas adalah perilaku pekerja migran selama berada di luar negeri (Malaysia) dan istri di daerah asal yang biasanya disebut sebagai Janda Malaysia (JAMAL) atau Perempuan Ditinggal Migrasi (PADMI).

Penelitian ini menggunakan metode studi kasus untuk mendapatkan gambaran tentang perilaku pekerja migran selama bekerja di Malaysia. Pertanyaan penelitian what, pada penelitian studi kasus digunakan pada tahapan explanatory study, sedangkan pertanyaan how dan why yang menjadi ciri dalam studi kasus diperdalam melalui observasi dan indepth interview (Yin, 2002), terkait perilaku pekerja migran seperti pemenuhan kebutuhan fisik, gaya hidup, pemenuhan kebutuhan seksual, intensitas berkabar, mengirim remitan, dan perilaku PADMI di daerah asal sebagai respon terhadap perilaku suami di Malaysia. Teknik pengumpulan data-data menggunakan observasi dan wawancara mendalam (indepth interview).

\section{PEMBAHASAN \\ Perilaku Pekerja Migran di Perkebunan Sawit}

Gaya hidup seseorang sering dikaitkan dengan peningkatan pendapatan, status ekonomi, pekerjaan, stress, aktivitas, dan kegemaran baru. Perubahan yang dialami seseorang di luar kebiasaan keseharian sebelumnya dapat terlihat nyata, seperti pada gaya berpakaian, penggunaan alat komunikasi, dan konsumsi. Terjadinya perubahan disebabkan berbagai faktor baik langsung maupun tidak langsung. 
Media cetak, elektronik, sumber-sumber tertulis merupakan faktor yang memiliki peran penting dalam menyumbang sebuah perubahan baik pada individu maupun kelompok. Pengaruh sumber-sumber inspirasi tersebut menyebabkan seseorang berpenampilan dengan gaya di luar kebiasaan.

Terkait konteks dalam penelitian ini, perilaku yang muncul sebagai hasil dari kebiasaan merupakan perwujudan kemauan atau keinginan yang bersangkutan untuk berbuat sesuatu. Kebiasaan hidup sederhana atau apa adanya sebelum menjadi pekerja migran akan berubah ketika mereka berada di Malaysia. Begitu besar pengaruh pendapatan terhadap gaya hidup seorang pekerja migran, sehingga tidak mengherankan perubahan terlihat dari mode dalam berpakaian, bahasa yang digunakan, pola konsumsi, dan kebutuhan hiburan. Berikut dipaparkan hasil observasi dan dialog mendalam terkait pemenuhan kebutuhan fisik, kebutuhan seksual, intensitas berkabar, dan mengirim remitan.

\section{Pemenuhan Kebutuhan Fisik}

Pemenuhan kebutuhan fisik seperti makan dan minum merupakan sesuatu yang sangat penting bagi setiap individu, termasuk bagi pekerja migran yang hanya mengandalkan kekuatan/tenaga fisik dalam bekerja. Berbagai kebutuhan hidup pekerja migran tersedia di kantin yang terdapat di perkebunan. Setiap bulan segala kebutuhan pokok diambil terlebih dahulu dan dibayar lunas saat pembayaran gaji. Pekerja migran makan tiga kali sehari dengan menu yang tersedia di kantin, sayuran, dan ikan air tawar di peroleh di sekitar tempat tinggal atau di areal perkebunan. Keterbatasan jenis menu dalam waktu yang lama membuat pekerja bosan, sehingga sekali sebulan pekerja migran refreshing ke kota untuk menikmati makanan sekaligus jalan-jalan.

Pengeluaran untuk kebutuhan fisik perhari berkisar antara RM15-RM30 dengan rincian sekali makan sebesar RM5RM10 sehingga secara keseluruhan jumlah pengeluaran pekerja migran setiap bulan sekitar RM450-RM900 atau setara dengan Rp 1.350.000-2.700.000. Perbedaan pengeluaran masing-masing pekerja diketahui dari total pengeluaran setiap bulan. Pekerja dengan pengeluaran lebih tinggi umumnya memiliki kebiasaan lain seperti merokok sehingga selain kebutuhan pokok, seper sepuluh dari pengeluarannya dialokasikan untuk membeli rokok. Total pengeluaran terbesar pekerja migran adalah untuk pemenuhan kebutuhan fisik karena bersifat rutin, sedangkan pengeluaran untuk kebutuhan lainnya bersifat insidental. Apabila pengeluaran hampir mendekati jumlah pendapatan maka seorang pekerja migran tidak akan dapat mengirim dalam jumlah yang cukup, sehingga harus dapat menekan pengeluaran semaksimal mungkin.

Kebiasaan merokok yang dibawa dari daerah asal semakin meningkat akibat kondisi di tengah perkebunan yang panas, sepi dan padatnya jam kerja, sedangkan mengkonsumsi minuman keras dilakukan pada saat malam mingguan atau ada acara tertentu, termasuk kegiatan membeli togel. Kasus yang sering dialamai rumah tangga pekerja migran adalah tersendatnya kiriman dan terganggunya komunikasi akibat penggunan pendapatan yang tidak terkendali.Wujud atau dampak langsung akibat penggunaan pendapatan yang tidak terkendali adalah terganggunya aliran pengiriman uang (remitan) kepada keluarga di daerah asal, di samping itu intensitas berkabar akan berkurang karena pekerja migran takut jika ditanya tentang uang kiriman oleh istri.

\section{Gaya Hidup}

Perubahan gaya hidup tercermin pada perilaku keseharian pekerja migran. Gaya hidup sederhana sebelum menjadi pekerja di Malaysia mengalami perubahan drastis setelah mendapatkan penghasilan berupa ringgit. Perubahan gaya hidup yang dialami sebagai upaya menekan rasa kesepian dan situasi pekerjaan yang cukup berat. Pola konsumsi makan-minum misalnya bergeser 
darikebiasaanminumkopi dipagihari beralih ke berbagai minuman bersoda, kebiasaan baru makan di restoran setiap bulan sekali berpengaruh langsung terhadap pendapatan yang akan dikirim kepada keluarga di daerah asal. Pergeseran gaya hidup dari sederhana menjadi konsumtif dialami setiap pekerja migran karena mereka beranggapan bahwa pendapatan yang diperoleh setiap bulannya sudah pasti.

Berdasarkan wawancara mendalam yang dilakukan, dalam menggunakan pendapatannya pekerja migran dapat diklasifikasikan menjadi pekerja migran yang menggunakan pendapatannya hanya untuk kebutuhan pokok dan pekerja migran yang menggunakan pendapatannya untuk memenuhi kebutuhan sampingan. Pengelolaan dan kontrol yang baik dalam menggunakan pendapatan berpengaruh langsung terhadap jumlah penghasilan yang dikumpulkan. Pekerja migran yang bergaya hidup sederhana dan menggunakan pendapatannya dengan bijak dapat menyisihkan sebagian penghasilannya setiap bulan untuk dikirim kepada keluarga di daerah asal. Bagi pekerja yang menggunakan pendapatanya secara tidak terkendali, menghadapi permasalahan terutama pada saat keluarga membutuhkan kiriman. Permasalahan yang dihadapi pada saat keluarga di daerah asal membutuhkan uang kiriman adalah persediaan sejumlah uang dari hasil pendapatan setiap bulan yang telah terpakai habis. Mengatasi hal tersebut pekerja migran terpaksa mencari pinjaman sementara kepada rekan sesama pekerja atau di tempat lain dan biasanya dilunasi pada saat pembayaran gaji.

\section{Kebutuhan Seksual}

Pemenuhan kebutuhan seksual bagi seseorang yang normal adalah wajar. Beberapa penelitian terkait pemenuhan kebutuhan seksual terhadap pekerja migran asal Indonesia pernah dilakukan. Penelitian Berliani (1999) dan Isyam (2009) menemukan bahwa sebagian besar responden menyalurkan kebutuhan seksualnya dengan mendatangi tempat lokalisasi, dengan teman sesama pekerja dan perempuan asli Malaysia yang mengalami masalah dalam keluarganya. Perempuan yang rumah tangganya mengalami broken home ini di Malaysia disebut dengan bohsia. Alasan melakukan hubungan seksual sesama pekerja atau pacar biasanya tidak mengeluarkan biaya terlalu tinggi bahkan gratis, tetapi jika melakukan hubungan dengan bohsia apalagi dengan PSK membutuhkan biaya tinggi karena biasanya perempuan-perempuan tersebut mendatangi tempat hiburan seperti cafe.

Besarnya biaya tingkah laku untuk pemenuhan kebutuhan seksual setiap kali berkencan/main (short time) relatif terjangkau. Menurut seorang pekerja asal Kediri Jawa Timur yang ditemui secara tidak sengaja saat menunggu bus di daerah Bintulu memberikan informasi sepintas tentang masalah prostitusi, sambil menunjuk ke arak sebelah kanan dari halte bus di dekat pasar Bintulu laki-laki berusia sekitar 35 tahun itu mengatakan" kalau mau cari-cari hiburan di sini, itu lho sebelah utara dekat pasar" kalau di situ tarifnya paling murah RM50 (Rp 150.000), ada juga yang lebih mahal sesuai kelas. Kalau mau yang lebih mahal ada juga antara RM100 (Rp 300.000) sampai RM200 (Rp 600.000) bahkan lebih. Apabila pengeluaran untuk kebutuhan pokok dijumlahkan dengan pengeluaran biaya tingkah laku maka dalam satu bulan seorang pekerja migran minimal mengeluarkan pendapatannya hingga RM740 (Rp 2.250.000), jumlah tersebut dapat meningkat tergantung kelas perempuan yang dipilih. Kebijakan pengelolaan pendapatan seorang pekerja migran berdampak terhadap pengiriman uang kepada keluarga di daerah asal, artinya semakin irit dan bijak dalam menggunakan sejumlah pendapatanya seorang pekerja migran memiliki kesempatan lebih besar untuk mengirimkan penghasilannya setiap bulan, sebaliknya pekerja yang boros dalam menggunakan pendapatan jarang mengirim uang. Seorang pekerja yang ulet dan mampu menekan pengeluaran untuk biaya yang 
tidak menguntungkan seperti merokok, membeli togel, dan biaya tingkah laku minimal dapat menyisihkan pendapatannya sekitar Rp 20.000.000 dalam setahun dengan menyisihkan sekitar Rp1.600.000 setiap bulannya.

Berbeda dengan penelitian sebelumnya, konteks penelitian yang dilakukan ini menemukan perbedaan perilaku pekerja migran terutama di perkebunan sawit. Sebagian besar dari sepuluh subjek penelitian mengakui memilih menahan diri untuk tidak melakukan hal-hal yang merugikan diri sendiri termasuk keluarga walaupun pernah terlintas dalam pikirannya. Hal ini terungkap dari hasil wawancara mendalam sebagaimana kutipan berikut,

"kalau ke tempat lokalisasi tidak pernah datang sama sekali, kadang pernah terlintas tentang hal itu, tapi ingat cerita orang-orang yang terkena penyakit menyebabkan saya dan kawan-kawan tidak mau mendatangi tempat seperti itu" (Kdn, 2012).

"tidak pernah sama sekali datang ke lokalisasi karena saya takut kena penyakit dan selalu ingat pesan orang tua dan istri. Kalau sedang ke kota pada saat gajian paling hanya sekedar ke mall atau ke pasar dengan teman-teman sekampung kadang berdua, tapi lebih sering ramai-ramai. Datang secara langsung tidak pernah tapi kalau lokasinya saya tahu karena kita sering melimpas (lewat) saja pada saat jalan ke pasar. Lokasi tempat tersebut bersebelahan dengan pasar bintulu" (Mhrp 2012).

Selain itu terdapat dua orang dari delapan subjek penelitian memenuhi kebutuhan seksualnya dengan memilih menikah sesama pekerja dengan beberapa alasan dan pertimbangan sebagaimana kutipan wawancara mendalam berikut,

Satu hal yang ada dalam pikiran saya bahwa lebih baik menikah sesama pekerja dari pada harus ke tempat seperti itu, karena saya sadar di tempat seperti itu adalah sarang penyakit. Bagaimana tidak sudah banyak orang yang singgah dan memakai pastilah ada bibit penyakit, kalau dengan istri kan dijamin aman. Selama di Gedong ini saya tidak pernah keluar jalan, apalagi bisa keluar ke tempat lokalisasi, baru pergi 1 atau 2 jam saja telepon berdering sampai 10 kali. Selain itu jarak gedong dengan kota cukup jauh (> $20 \mathrm{~km})$, dan karena tidak punya SIM jadi takut keluar-keluar " (Hrtw, 2012).

Dari tiga subyek penelitian tersebut menggambarkan bahwa kekuatiran akan penularan penyakit menjadi alasan utama mengapa mereka tidak mendatangi atau menyalurkan hasrat seksualnya di tempattempat lokalisasi. Selain takut tertular Penyakit Menular Seksual (PMS), mengingat pesan orang tua dan istri di kampung mampu menekan keinginan untuk melakukan hal-hal yang merugikan. Berbeda dengan Kdn dan Mhrp, Hrtw mengakui selain takut tertular penyakit untuk menghindari keinginan melakukan hubungan seksual di tempat lokalisasi dengan PSK lebih memilih untuk menikah dengan sesama pekerja migran karena itu lebih aman. Pilihan tersebut dibuktikan pekerja migran berusia 46 tahun ini yang menikah sebanyak tiga kali selama menjadi pekerja di Malaysia.

Alasan dan pertimbangan kelompok yang mampu menahan diri maupun mereka yang memilih menikah sesama pekerja tidak jauh berbeda. Kelompok pertama beralasan memilih menahan diri karena selain takut tertular penyakit, kondisi keuangan yang tidak memungkinkan. Kelompok ke dua memilih opsi menikah dengan alasan pilihan lebih tertuju untuk sekedar menyalurkan hasrat seksual dan sebagai antisipasi terhadap perilaku seks bebas, juga menekan pengeluaran. Perkawinan sesama pekerja migran di perkebuan sawit bersifat sementara artinya pernikahan yang dilakukan hanya pada saat mereka menjadi pekerja migran karena umumnya pekerja migran laki-laki telah menikah di daerah asal. Kebiasaan yang terjadi setelah selesai masa kontrak kerja, masing-masing akan kembali ke daerahnya, tetapi tidak jarang pernikahan sesama pekerja migran ada yang berlanjut setelah selesai masa kontrak. Pernikahan serius biasanya bagi mereka yang samasama masih lajang, sehingga setelah selesai masa kontrak, pekerja migran bersangkutan 
akan melakukan prosesi pernikahan ulang di daerah asal pekerja laki-laki atau perempuan. Kasus pernikahan sesama pekerja di perkebunan sawit diceritakan Hrtw, yang menikahkan seorang pekerja migran asal Bima NTB dengan perempuan pekerja migran asal Sambas Kalimantan Barat. Setelah masa kontrak berakhir kedua pasangan pekerja migran tersebut melakukan nikah ulang di Sambas.

\section{Intensitas Berkabar}

Berkabar adalah satu bentuk hubungan keterikatan antara dua orang atau lebih yang terpisah oleh jarak dan waktu. Hubungan menggunakan alat komunikasi diperlukan untuk membangun dan mempererat ikatan perkawinan yang terpisah sementara waktu. Kesetabilan hubungan antara pekerja migran dengan istri tetap terjaga dengan lancarnya komunikasi atau terjalinnya komunikasi selama terpisah oleh jarak dan waktu. Terkait kontek penelitian yang dilakukan terganggunya komunikasi antara pekerja migran di malaysia dan istri di daerah asal tidak jarang berdampak pada menurunnya kualitas hubungan yang berakhir dengan disintegrasi rumah tangga.

Istri pekerja migran di daerah asal selain menunggu kiriman uang, berharap mendapat kabar tentang keadaan suami selama di daerah tujuan. Harapan besar untuk medapat kabar dari suami terganggu oleh keadaan yang dialami setelah sampai di daerah tujuan. Gaya hidup konsumtif dan pengendalian tingkah laku yang tidak terarah dan berpengaruh langsung pada intensitas berkabar. Seorang pekerja migran yang dalam kesehariannya tidak dapat mengendalikan perilakunya, terlihat dari seberapa intens menghubungi istri di daerah asal. Rendahnya intensitas berkabar mengindikasikan adanya gangguan pada perilaku pekerja migran dalam bentuk menikah dengan sesama pekerja, boros, dan suka mendatangi tempat lokalisasi.

Gaya hidup konsumtif dan perilaku seksual pekerja migran selama di Malaysia berhubungan erat dengan intensitas berkabar artinya semakin konsumtif membelanjakan pendapatanya, melakukan pernikahan dan suka mendatangi tempat prostitusi mempengaruhi intensitas berkabar kepada istri di daerah asal.

\section{Intensitas Mengirim Remitan}

Selain menunggu kabar hal penting yang menjadi harapan setiap rumah tangga (istri) yang ditinggal migrasi adalah uang kiriman. Harapan akan uang kiriman melebihi kabar berita karena seorang istri tidak cukup hanya dengan kabar berita, tetapi membutuhkan uang untuk kelangsungan hidup selama ditinggal. Meningkatnya kebutuhan hidup baik untuk pemenuhan kebutuhan fisik maupun keperluan pembiayaan keluarganya di daerah asal menuntut tanggungjawab seorang pekerja. Alasan dan motivasi seorang pekerja migran melakukan migrasi berbeda-beda seperti perbaikan ekonomi rumah tangga dan investasi jangka panjang berupa kelangsungan pendidikan anak-anak mereka, walaupun terdapat juga alasanalasan non-ekonomi. Selama ini pekerja migran asal Lombok Timur melakukan migrasi ke Malaysia lebih didominasi faktor ekonomi. Keinginan memiliki rumah yang bagus, lahan sawah, ternak, dan peralatan elektronik yang bagus menjadi sesuatu yang utama.

Terpenuhi tidaknya permintaan keluarga akan remitan pada saat-saat membutuhkan akan terjawab oleh perilaku yang dialami individu pekerja migran. Bagi mereka yang sadar dan berpikir bijak umumnya tidak mengumbar nafsu untuk berlaku konsumtif karena memiliki tanggung jawab terhadap anak dan istri di daerah asal. Sebaliknya pekerja migran yang lupa diri dan keluarga dengan berbagai alasan pada gilirannya menghadapi masalah saat anak dan istri membutuhkan uang untuk kelangsungan hidup.

Terkait kasus penelitian yang dilakukan, ditemukan pekerja migran yang intens mengirim remitan, pernah mengirim hanya sekali selama menjadi pekerja dan tidak pernah sama sekali. Kasus pekerja migran 
yang tidak pernah mengirim remitan diketahui dari hasil wawancara dengan istri di daerah asal. Hasil wawancara mendalam dengan istri pekerja migran di daerah asal terhadap sikap pasangannya selama di negeri Jiran disikapi berbeda. Terdapat istri yang bertahan dengan penuh kesabaran menunggu kiriman, tetapi tidak jarang ada yang emosional ditunjukkan dengan melakukan tindakan yang kurang bijak. Tindakan yang kurang bijak dalam bentuk pelanggaran norma sosial, budaya, dan agama seperti perselingkuhan atau hubungan tanpa status.

Singkatnya dapat dikatakan bahwa intensitas seorang pekerja mengirim remitan terkait erat dengan perilaku selama bekerja di luar negeri. Semakin irit penggunaan pendapatan di Malaysia semakin intens mengirim remitan ke daerah asalnya. Dengan kata lain bahwa perilakua pekerja migran berbanding terbalik dengan intensitas mengirim remitan artinya semakin konsumtif seorang pekerja migran semakin kecil peluang untuk mengirim remitan kepada keluarga atau sebaliknya.

\section{Perilaku PADMI \\ Mempertahankan Kelangsungan Hidup Keluarga}

Peralihan tugas dan tanggungjawab sementara dari suami kepada istri merupakan hal yang wajar di daerah-daerah pengirim pekerja migran. Tugas dan tanggungjawab seorang PADMI tidak hanya sebatas pemenuhan kebutahan fisik, tetapi lebih dari itu mengatasi tekanan ekonomi dan psikologis sekaligus mempertahankan keutuhan rumahnya. Sepeninggal suami ke Malaysia tongkat estapet tanggungjawab pemenuhan kebutuhan hidup selama menunggu kiriman adalah tugas istri. Menghadapi situasi setelah keberangkatan suami ke luar negeri, strategi yang dilakukan PADMI yaitu mencari pinjaman sebagaimana penggalan kutipan wawancara mendalam berikut.

"......selama menunggu kiriman, saya pakai uang pinjaman dari Santren. Uang santren itu hasil dari sumbangan warga, dari uang yang terkumpul dipinjam oleh warga yang butuh. Selama ditinggal pekerjaan yang dikerjakan jadi buruh, nyabut bibit padi dengan ongkos Rp15.000 setengah hari dan Rp30.000 sehari, kadang buruh tembakau (06.30-11.00 dan 14.0017.30).... (HsKh, 20 Desember 12)".

Demikianlah strategi $H s K h$ yang sudah 12 tahun ditinggal suami ke Malaysia. Tanggungan tiga orang anak yang salah satunya berstatus mahasiswa, perempuan penderita paru-paru basah ini tetap semangat, selain HsKh, PADMI lain menuturkan pengalamannya.

"...... Dia tidak pernah ngirim sama sekali, kecuali waktu di Bintulu saat belum menikah dengan istrinya yang sekarang. Waktu itu pernah mengirim uang sekitar 5.5 juta dan sisa hutang suami saya sekitar 1 juta. Terakhir dia sempat mengirim uang 2000RM, dan sy disuruh untuk menyelesaikan sisa hutang sekitar 500rb, tapi saya jawab tidak mau, karena untuk memenuhi kebutuhan sehari-hari ......(Sni, Desember 2012)".

Selain bergantung terhadap pinjaman, seorang PADMI mengandalkan orang tua. Hal ini sejalan dengan penelitian (Tajuddin, 2006) di Kabupaten Lombok Barat bahwa cara yang ditempuh rumah tangga migran untuk bertahan hidup selain dagang, buruh tani, dan industri kerajinan rumah tangga adalah kembali pada orang tua.

\section{Respon PADMI terhadap Perilaku Suami di Malaysia}

Konsekuensi perpisahan sementara sebagai akibat langsung aktivitas migrasi melahirkan gejolak dalam rumah tangga pekerja migran. Ikatan dan hubungan yang terjalin mulai tergerus jarak, komunikasi tidak lancar dan kiriman tak kunjung datang. Jarak dan kiriman yang belum datang relatif dapat dipahami sejauh komunikasi lancar anatara suami istri. Dalam konteks penelitian yang dilakukan kesepian dan kesendirian dapat dialami PADMI. Kesepian dapat memunculkan gejolak pribadi dalam bentuk stress. Setiap personal menyikapi 
rasa stress dengan cara masing-masing, ada yang mengelola secara positif, dan ada juga menghadapi stress dengan melakukan halhal negatif. Kegiatan positif seperti, menjadi buruh tani, buruh bangunan dan menghadiri majelis ta'lim sedikit menekan kesepian; sedangkan mereka yang tak berpikir memilih cara lain dengan melakukan perselingkuhan. Berikut ungkapan PADMI terkait perasaan.

"perasaan saya kalau di tinggal untuk mencarikan anak-anak tidak apa-apa yang penting anak-anak dapat sekolah, ikhlas dan tidak apa-apa. Tidak begitu caranya tidak dapat kita makan-minum. Kita tidak punya sawah, cobalah lihat rumah saya untung tidak hujan saja, tapi maunya yang bagus-baguslah" (HsKh, Desember 2012).

\begin{abstract}
"perasaan ditinggal suami sangat kecewa, nanti ada saja balasan dari Allah. Saya bilang ke dia mungkin situ mau pulang ke Timor-Timur ( maksudnya NTT). Saudara sepupu dia di sini bertanya semua, bagaimana kabarnya? Dan saya jawab tidak ada" (Sni, Desember 2012).
\end{abstract}

Perasaan sedih dan kecewa PADMI adalah wajar karena kebersamaan yang pernah dilalui bertahun-tahun berubah menjadi suasana sepi ditambah beban tanggung jawab atas diri dan keluarga hingga berjibaku dengan gangguan pihak ketiga. Kondisi nyata di lapangan menunjukkan kecendrungan PADMI pernah diganggu oleh pihak ketiga. Pengalaman HsKh dan Sni, membuktikan gangguan dari laki-laki sekampungnya. Bentuk gangguan yang masih dalam kewajaran biasanya direspon baik, dengan alasan sebagai hiburan. Gangguan dalam batas kewajaran yang dimaksud berupa sms atau telepon dari pihak ketiga yang berisi ajakan untuk bertemu atau jalan-jalan. Biasanya ajakan tersebut ditolak secara halus dengan alasan tidak ada kesempatan untuk jalan-jalan karena sibuk sebagai buruh tani atau bangunan. HsKh dan Sni menambahkan jika gangguan pihak ketiga tidak direspon dengan serius, biasanya mereka tidak akan mengganggu lagi.

Berbeda dengan mereka yang masih berusia lebih muda, pekerjaan menjadi buruh tani relatif jarang dilakukan, apalagi mengikuti majelis ta'lim karena alasan umur, perbedaan pandangan dan cara berpikir seperti Mlnd dan $\mathrm{Nr}$, dua orang PADMI yang lebih dua tahun ditinggal migrasi suaminya menjalani kehidupannya seharihari sebagaimana terangkum dalam kutipan hasil wawancara berikut.

\begin{abstract}
" pertama-tama perasaan ditinggal ke malaysia biasa aja rasanya, tapi lama-lama kesepian jadinya. Apalagi ngirimi uang jarang, terus terang karena kesepian terpaksa saya lakukan (berselingkuh), padahal saya suruh dia pulang terus tapi tidak pulang-pulang" (Mlnd, Desember 12).

"........kita masih muda, siapa yang tahan 4 sampai 5 tahun?Sebagai manusia hati kita tidak slalu tabah menerima, terkadang marah juga rasanya, kenapa suami saya seperti ini, menghianati saya. Terus terang kadang saya malu dengan anak, tapi namanya kita manusia kadang banyak hilap, dengan cara itu kita sebagai perempuan balas dendam..... (Nr,Desember 2012).
\end{abstract}

Jika dibanding dengan dua PADMI sebelumnya, Mlnd dan $\mathrm{Nr}$ yang berusia lebih muda relatif berani melakukan tindakan terlarang dengan alasan jarang mendapat kiriman dan balas dendam terhadap perlakuan suaminya. Lelaki yang pernah dekat dengannya selalu memberikan uang. Besar kisaran uang yang diberikan mulai 200 hingga 500 ribu. Alasan mengapa melakukan itu adalah untuk pemenuhan kebutuhan sehari-hari karena tidak pernah mendapatkan kiriman rutin dari suaminya. Kalaupun mendapatkan kiriman hanya untuk membayar hutang biaya bermigrasi dan cicilan kendaraan bermotor. Hasil wawancara mendalam menunjukkan subyek penelitian (Mlnd) sering bertemu dan melakukan hubungan dengan laki-laki lain. Pertemuan Mlnd dengan orang-orang yang memiliki hubungan khusus dengannya sebagai bentuk protes terhadap suaminya, selain itu untuk menghalau rasa kesepian dan kegelisahan. Lokasi yang paling sering dijadikan tempat bertemu dan bercumbu adalah di tepi pantai sebuah tempat wisata 
yang tidak jauh dari tempat tinggalnya, dan untuk menghindari gangguan orang biasanya dilakukan menjelang magrib.

Berbeda dengan Mlnd, subyek penelitian berinisial $\mathrm{Nr}$ berkecenderungan untuk merahasiakan aktivitas berkaitan dengan pemenuhan kebutuhan seksualnya karena merasa risih. Nr tidak berani berterus terang pada saat wawancara mendalam, tetapi dari bahasa tubuhnya terlihat sangat berpengalaman dan memiliki banyak teman laki-laki. Hal ini diperkuat ungkapan teman dekatnya yang sempat diwawancara.

"dia itu sebenarnya sangat berpengalaman, maksud saya banyak teman laki-lakinya dan sering janjian untuk ketemuan, apa yang dia ceritakan dalam wawancara tadi benar adanya, Cuma masih ada kurangnya, karena pengakuan yang diungkapkan tadi masih kurang, kalau dia mengatakan tidak pernah berhubungan intim dengan laki-laki lain itu tidak benar, karena dia sering cerita kalau sudah ada kencan dengan laki-laki lain ke saya.... bapak bisa pahamlah".

Perilaku PADMI di daerah penelitian selama ini terkesan terselubung, tetapi dampaknya terlihat nyata yang ditunjukkan oleh jumlah kasus perceraian di Lotim menempati urutan pertama dibanding kabupaten/kota lainnya di NTB. Pada tahun 2010-2011 jumlah kasus perceraian sebagaimana pernyataann kepala PA Selong yang dilansir salah satu koran di NTB bahwa "setiap tahun kasus perceraian di Lotim mengalami peningkatan". Penanganan perkara perceraian selama tahun 2010 sebanyak 724 kasus, dari sejumlah kasus tersebut $613(84,6 \%)$ kasus cerai gugat, dan sisanya cerai talak, sedangkan pada 2011, dari bulan januari hingga Juli kasus yang ditangani sebanyak 442 kasus, yang terdiri dari $370(83,7 \%)$ kasus cerai gugat dan sisanya cerai talak. Pada awal tahun hingga bulan april 2013 tercatat permohonan cerai gugat sebanyak 73 kasus perkara, dan 55 $(75,3 \%)$ di antaranya adalah kasus cerai gugat, 8 kasus cerai talak dan sisanya kasus lain. Angka penanganan perkara perceraian di PA Selong sebagaimana data di atas menunjukkan trend yang relatif menurun, tetapi aspek penekanan penelitian ini bukan melihat prosentase kasus secara umum setiap tahunnya melainkan prosentase kasus cerai gugat yang didominasi rumah tangga pekerja migran. Keberanian kaum perempuan Sasak yang selama ini dianggap dan diposisikan nomor dua akibat ideologi patriarki mengalami perubahan baru akibat aktivitas migrasi terutama migrasi internasional.

\section{SIMPULAN}

Migrasi internasional ke luar negeri memberi pengaruh terhadap sifat migran setelah di Malaysia dalam bentuk budaya konsumerisme seperti kebiasaan makan di restoran walaupun hanya sekali dalam sebulan. Perubahan perilaku dan kebiasaan baru pekerja migran dalam bentuk penggunaan pendapatan untuk belanja kebutuhan pokok dan kebutuhan sampingan berkembang sebagai alasan untuk mengatasi kejenuhan. Penggunaan pendapatan yang tidak terkendali menyebabkan gangguan terhadap intensitas menghubungi keluarga di daerah asal termasuk di dalamnya intensitas mengirim remitan.

Dua hal yang dilakukan pekerja migran di lokasi penelitian terkait pemenuhan kebutuhan seksual pertama, melakukan pernikahan dengan sesama pekerja di perkebunan dengan alasan sebagai antisipasi terhadap perilaku sek bebas di samping menekan pengeluaran. Kedua, menahan diri untuk tidak melakukan sesuatu yang merugikan diri sendiri. Penelitian yang dilakukan menemukan bahwa sebagian besar pekerja migran mengakui tidak pernah mengunjungi tempat lokalisasi karena jaraknya jauh dan takut tertular penyakit kelamin serta mengingat pesan orang tua dan istri di kampung.

Respon PADMI terhadap perilaku suami di Malaysia berbeda-beda yang ditunjukkan oleh sikap dan perilaku selama ditinggal bermigrasi. Disatu sisi terdapat PADMI yang menyikapi perilaku suami dengan bersabar dan menunggu sampai suami kembali, rasa jenuh dan kesepian dihalau dengan 
kegiatan bermanfaat menjadi buruh tani dan bangunan. Di sisi lain terdapat PADMI yang melampiaskan kekecewaan dengan melakukan perselingkuhan atau menjalani hubungan tanpa status sebagai bentuk balas dendam atas perilaku suami.

\section{UCAPAN TERIMAKASIH}

Terimaksih disampaikan kepada Konsulat Jenderal Republik Indonesia beserta staf di Kuching Malaysia Timur yang telah memberikan izin untuk terlaksananya penelitian ini dan pekerja migran asal Indonesia di Serian dan Bintulu yang membantu mendampingi selama kegiatan penelitian dilakukan.

\section{DAFTAR PUSTAKA}

Amrullah, A. 2009. NTB Klaim Miliki Janda Terbanyak. http://www. nasionalvivanews. Com. 5 Februari 2012.

Bahransyaf, D. 2009. Cerai Gugat Mendominasi Perceraian di Indonesia. Penelitian Kesejahteraan Sosial. 33(1): 43-48.

BP3TKI. 2011. Data Penempatan Tenaga Kerja Indonesia asal Nusa Tenggara Barat. Mataram.

Berliani, H. 1999. Perilaku Seksual Pekerja Migran. Pusat Penelitian Kependudukan Universitas Gadjah Mada. Yogyakarta.

Castles, S. 2009. Development and Migration or Migration and Development: what comes first? Asian and Pacific Migration Journal.18(4): 441-471.

De Haas, H. 2010. Migration and Development: A Theoretical Perspective. International Migration Review. 44(1). 227-259.

Disosnakertrans. 2012. Data Penempatan Tenaga Kerja Indonesia. Disosnakertrans Lombok Timur.

Dinas Tenaga Kerja. 2005. Analisis Lembar Informasi Ketenagakerjaan. Triwulan I. Dinas Tenaga Kerja Nusa Tenggara Barat.
Eversole, R. dan J. Shaw. 2010, Remittance flows and their use in households: A comparative study of Sri Langka. Indonesia and the Philipines Asian and PacificMigration Journal.19 (2). 175-201.

Goma, J.N. 1993. Mobilitas Tenaga Kerja Flores Timur ke Sabah Malaysia dan Pengaruhnya Terhadap Daerah Asal. Studi Kasus Desa Neleran Kecamatan Adonaru Kabupaten Flores Timur. Tesis. S2 Kependudukan UGM.

Haris, A. 2002. Memburu Ringgit Membagi Kemiskinan: Fakta di Balik Migrasi Orang Sasak ke Malaysia. Yogyakarta: Pustaka Pelajar.

2004. Migrasi Internasional dan Derap Pembangunan Daerah: Studi Pemanfaatan Remitan di Kabupaten Lombok Timur Nusa Tenggara Barat. Disertasi. Program Doktor Studi Kependudukan Universitas Gadjah Mada Yogyakarta.

Hugo, G., 2001. "Effects of International Migration on the Family in Indonesia". Asian and Pacific Migration Journal.11(1).13 - 40.

Hugo, G., U. Swarna. 2010." Sri Langkan Female Domestic worker overseas the impact on their children". Asian and Pacific Migration Journal.19 (2). 237-263.

Isyam, M. 2009. Perilaku dan Kehidupan Seksual Pekerja Migran. Penelitian Kesejahteraan Sosial.33(3). 2009.

Lee, E.S. 1969. A theory of migration In Sociological studies 2: Migration (ed. J.A. Jackson), London N.W.I: Cambridge At The University Press. Terjemahan I.B Mantra. Pusat Studi Kependudukan dan Kebijakan Universitas Gadjah Mada, Yogyakarta.

Mantra, I. B. Kasto, dan Y. T. Keban. 1999. Mobilitas Tenaga Kerja Indonesia ke Malaysia. Yogyakarta. Pusat Penelitian Kependudukan Universitas Gadjah Mada Yogyakarta. 
Notoatmodjo, S. 2003. Pendidikan dan Perilaku Kesehatan. Jakarta: Rineka Cipta

Sevoyan, D.A., S.T. Yabiku, dan V. Agadjanian. 2010. Husbands' Labour Migration And Wives' Autonomy. Mozambique 2000-2006. A Journal of Demography. 64(3). 293-306.

Tajuddin, L. 2006. Penerimaan dan Pemanfaatan Devisa Pekerja Migran di Kabupaten Lombok Barat. Tesis. S2 Kependudukan Universitas Gadjah Mada.Yogyakarta.

Taylor, S.E, L.A. Peplau, dan D.O. Sears. 2009. Social Psychology (Edisi 12 Terjemahan), Jakarta: Kencana.
Sukamdi. 2007. Memahami Migrasi Pekerja Indonesia ke Luar Negeri. Populasi 18(2). 115-128.

Wahyono, S. 2008. The Problems of Indonesian Migrant Workers :Rights Protection in Malaysia. Jurnal Kependudukan Indonesia.LIPI.II (1). 27 - 43.

Wulan, T. R. 2007. Pengetahuan dan Kekuasaan: Penguatan Remitansi SosialsebagaiStrategi Pemberdayaan Buruh Migran Perempuan Indonesia. Warta Demografi tahun 37( 2). 8 - 20.

Yin, R. K. 2002. Studi Kasus Desain dan Metode. Jakarta :PT Raja Grafindo Persada. 